\title{
Development on the Learning Module of School-Based Supervision Course for Master Degree Students, Majoring Educational Administration in Thailand
}

\author{
Chaiyuth Sirisuthi ${ }^{1} \&$ Chalard Chantarasombat ${ }^{1}$ \\ ${ }^{1}$ Faculty of Education, Northeastern University, Thailand \\ Correspondence: Chaiyuth Sirisuth \& Chalard Chantarasombat, Faculty of Education, Northeastern University, Khon \\ Kaen Province, Thailand. Tel: 66-432-229-5961. Email: chaiyuth.sir@neu.ac.th; Email: chalard.cha@ neu.ac.th
}

Received: January 18, 2021

Accepted: January 29, 2021

Online Published: February 1, 2021

doi:10.5430/ijhe.v10n4p21

URL: https://doi.org/10.5430/ijhe.v10n4p21

\begin{abstract}
This paper described the development process and evaluations of a learning module, School-based Supervision of Students (ED8013307), of master's degree students in Educational Administration during the academic year 2019 at Northeastern University, Khon Kaen, Thailand. The results of the learning module found the efficiency of the learning module was higher than the specified criterion of 80/80, both in the action process (84.76) and in the efficiency of knowledge (82.16). The developed module had its quality, propriety, congruence, feasibility and utility at the highest level. The effectiveness index in students' learning management was 0.7578 indicated the increasing knowledge of the students at $75.78 \%$ as their learning achievement-test was significantly higher than the pre-test at 0.05 . Beside these, there were no significant differences between pre-test and post-test learning achievement after 2 weeks indicating that they have had their learning retention. The students expressed overall satisfaction with the learning module at the highest level.
\end{abstract}

Keywords: learning module development, school-based supervision, masters' degree action learning

\section{Introduction}

\subsection{Rationale}

Changing demographics was challenging the ability of master's degree program students in Educational Administration at Northeastern University, Thailand. The sustainability and viability of transferring knowledge to the next generation through traditional methods were circumvented by the trend of students relocating to more urbanized areas of Thailand. It has been an important goal of Thailand's education policies (2018-2037), the $12^{\text {th }}$ Issue of National Economic and Social Development Plan, and Thailand's National Education Act that Thai students must possess the skills for the $21^{\text {st }}$ century. The role of teachers should be changed to be more coaches, facilitators, and those who exchanged knowledge. They should cooperate with their students systematically and continuously, based on the students' requirement, in order to share their learning experiences. A learning module was an innovative learning technique as it focused on the students' learning by summarizing the exact question for students to be able to apply and continuously follow-up their learning, made students interested in their class, and wanted to learn more to express their own creativity. Thus, developing a learning module "School-based Supervision of Students (ED8013307)" which was focused on students' learning through practices should be beneficial for master's degree students in Educational Administration at Northeastern University, Thailand.

\subsection{Background}

Rapid economic, environmental and social development changes have impacted every countries. Unskilled or low skilled labor were more likely than ever to be eventually replaced by robotics and technology. Every country was determined to raise production levels with competent and specialized skilled human resources. These demands could be achieved through education and educational management. In response to the changing trend, Thai educational management was focused on the $21^{\text {st }}$ century skills of students with the goal for students to obtain the necessary knowledge and skills for use in their daily life, career advancement and contribute to the development of the national economy and Thai Society. The educational management should be aligned with Thailand's education policies which were the 20-year national strategy (2018-2037), the $12^{\text {th }}$ Issue of National Economic and Social Development Plan, and 
Thailand educational management development which were supported by the Sufficiency Economy Philosophy. They emphasized the development goal to develop Thais of all age levels in every dimension of human resources to be skillful, competent and self-developed citizens. Thai human resources, including Thai students, for the $21^{\text {st }}$ century should be virtuous, intelligent, and quality individuals who have had public awareness and responsibility to society and others. They should be economical, generous, disciplined, ethical and respectable citizens. Beside these, they must have decent English and foreign language skills, learning oriented, and pursue self-development. According to the goal, Thai students must possess the skills of 3Rs8Cs which included: reading, writing, and arithmetic. They must also possess the 8Cs comprising: analytical thinking, critical thinking, problem-solving, creativity, innovation, understand the cultural differences, and have cross-cultural appreciation, can collaborate with others, are good team players and also leaders that can guide others. They should also possess ethics, mercy, discipline, and compassion (Institute of Community Colleges, Ministry of Education, Thailand, 2018).

The role of teachers, the most important resource in educational quality development and were tasked with providing and developing education so that students obtained knowledge and competency with complete potentiality, must be under the current context and environmental situation of global society as well as to adapt to the changes that based on the students' requirements including external factors such as social-cultural trends, information, communication, and technology. The Educational Management Guidelines stated on the $3^{\text {rd }}$ Issue of Thailand's National Education Act, Category 4, Section 24 (5) that the schools and related working units must enhance and support the teachers to provide the classrooms' climate, environment, learning media, and facilities for their students' education. It also stated that the schools should develop efficient instructional processes to support teacher's ability to research and develop suitable learning processes with their students. Moreover, teachers must apply various instructional management techniques that are essential to change or develop the new concepts appropriated for contemporary (Dechakup, 2011). Their roles were changed from just presenting lectures in front of classrooms to being facilitators or coaches who provided suggestions, recommendations, and assistance when needed. The changing roles were supported by Panich's assertion (Panich, 2013), that the teachers had to change their roles from lecturers and become more coaches and initiators. To create a sustainable new learning management network, teachers and students should systematically and continuously share their learning experiences called Professional Learning Community (PLC).

New learning management network could make a pleasant learning experience which is the ideal instructional management setting. Teachers and instructors should seek out various learning techniques and adopt them in the student's development. The important factors to contemplate included: the lessons must be useful, meaningful, the learning activities should be diverse, the learning media should be interesting, evaluation should be emphasized on each student's potential, the interaction between the teachers and students should be friendly, compassionate, encouraging and be supportive of each other.

The learning module was an instructional management technique that innovated with a collection of learning contents with technology in order to be able to enhance the learning potential of students. It could revise and improve the different courses or educational processes to be more efficient. Edmonds (1994) who constructed the learning module for enhancing and encouraging patients being treated by Nitroglycerin, found that the learning module increased their knowledge and morale more than those that only studied through documents at .001 level. In Thailand, there were many studies on the modules found its efficiency in high effectiveness index significantly above the specified criterion 80/80 (Suda, 2005; Donbundit, 2008; Inruangsri, 2011; Krongtanoen, 2016; Hasakool, Chianchana, \& Stirayakorn, 2016; Paphaphasid, 2018; Chantarasombat, 2020; and Chantarasombat, \& Meekhamtong, 2020). These results seem to confirm the benefit of the learning module, an effective educational innovation, that it could assist students in achieving their full potential and was appropriate for teachers to utilize in the development of students. The learning module emphasized on being student-centered, the students must interact and participate as a student as well as to be a teacher in their classroom in order to be capable of applying the gained knowledge. By the learning process, they could develop new knowledge and also their innovative thinking through self-learning processes and through their teamwork. The individual or group activities in the module focused on authenticity and real-world situations that students would have direct experience and properly exercise their skills (Koonchon Na Ayutthaya, 1993; Charoenpong, 2012, July; Dechakup, 2011; Khammani, 2013; Chantarasombat, 2018).

The module achievement could be reached if it was developed step by step in a systematic instructional process including various teaching methods used for self-studying based on individual differences and the efficiency of the module carefully investigated (Lawrence, 1973; Sigkabundit, \& Sigkabundit, 2011). Thus, it could help students keep paces with their education and reveal the student's level of competency or progress in each stage. According to the achievements, the learning module development process was a significant step of learning achievements. By studying the Southeast Asia countries in developing process of the module, there were 5 steps in the developing: 1) Content 
analysis by researching, assessing or by defining 2) Design the module 3) Implement 4) Developing and revision 5) Evaluation (Fajaryati, Nurkhamid, Pranoto, \& Muslikhin, 2016; Kowitlawakul, Chan, Tan, Soong, \& Chan, S. W. C., 2017; Elmunsyah, Anggraeni, \& Handayani, 2017, November; Efendi, Musnir, \& Situmorang, 2019, February; Daryono, \& Rochmadi, 2020). Most of them used research and development research methods and students took their roles only in the evaluation step whether the models were feasible or not.

There were many universities in Thailand that provided learning management through learning modules. However, there were a few research studies on learning modules development in higher education, including the Bachelor's Degree, master's Degree, and Doctoral Degree Students. The authors agreed with instructors at Northeastern University and collaborated with them in the master's degree program, Educational Administration during the first semester of 2019 to develop a major pilot course, School-based Supervision of Students (ED8013307), for studying the appropriate innovation in the form of a learning module. The module was focused on students' learning through practice, action learning, creative thinking, innovative development, expert competence, creation of new knowledge and the ability to transfer that knowledge by coaching and instructing others. The goal of the module was to be an efficient and effective criterion that could be extended to interested individuals, groups and benefit higher educational institutions in the future.

\subsection{Research Questions}

1) How to design, construct and develop the learning module "School-Based Supervision of Students (ED8013307)"?

2) What level of the model evaluations in its propriety, feasibility, congruency, and utilities, its effectiveness in the learning management for the students be?

3) What would the students' learning achievement and learning retention be?

4) What level of satisfaction would the students have to the module?

\subsection{Research Objectives Are as follows}

1) To construct and develop the learning module

2) To evaluate the quality of the learning module in its effectiveness, the students' learning achievement, the students' learning retention and the students' satisfaction.

\subsection{The Delimitation of Research}

1) The population of this study consisted of 14 selected and 12 volunteer Master's Degree students in the Educational Administration of Northeastern University, Khon Kaen, during the first semester of the 2019 academic year. The participants were registered students

who studied and continuously participated in the program "School-Based Supervision for Students" (ED8013307)

2) The independent variable was the learning management of the learning module. The dependent variables included learning achievement and satisfaction.

3) The duration of the study was conducted during the first semester of the 2019 academic year.

4) The content materials were divided into learning units or sub-modules which include: 1) Supervision Planning, 2) Technique for Higher-Order of Supervision, 3) Educational Quality Assurance, 4) Enhancement of Student Support System and 5) Development of Supervision Network.

\subsection{Research Conceptual Framework}

The development of the learning module of "School-Based Supervision for Students" and the conceptual framework was determined by the authors with experts' evaluations. The innovation of learning module of "School-Based Supervision for students" consisted of 5 learning sub-modules including 1) Supervision Planning, 2) Technique for Higher-Order of Supervision, 3) Educational Quality Assurance, 4) Enhancement of Student Support System and 5) Development of Supervision Network. As show by Figure 1 


\section{Learning module Innovation: School-Based Supervision \\ 1) Supervision Planning \\ 2) Higher-Order of Educational Supervision Technique \\ 3) Educational Quality Assurance \\ 4) Promotion of Student Support System \\ 5) Construction of Supervision Network \\ $\uparrow$ \\ Management (Administrator \& School Administrator) \\ - focused on staying in school and classroom visits. \\ - school monitoring and evaluation as a professional learning community.}

Supervisor: Research and Program Development, and Demonstration School in Basic Educational Level. Outcome: Higher Learning Performance of School

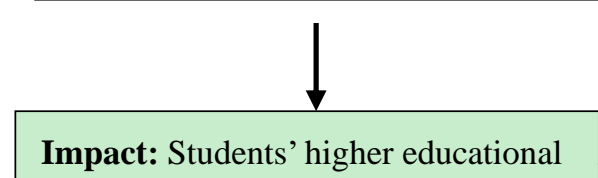

Quality: Community Network

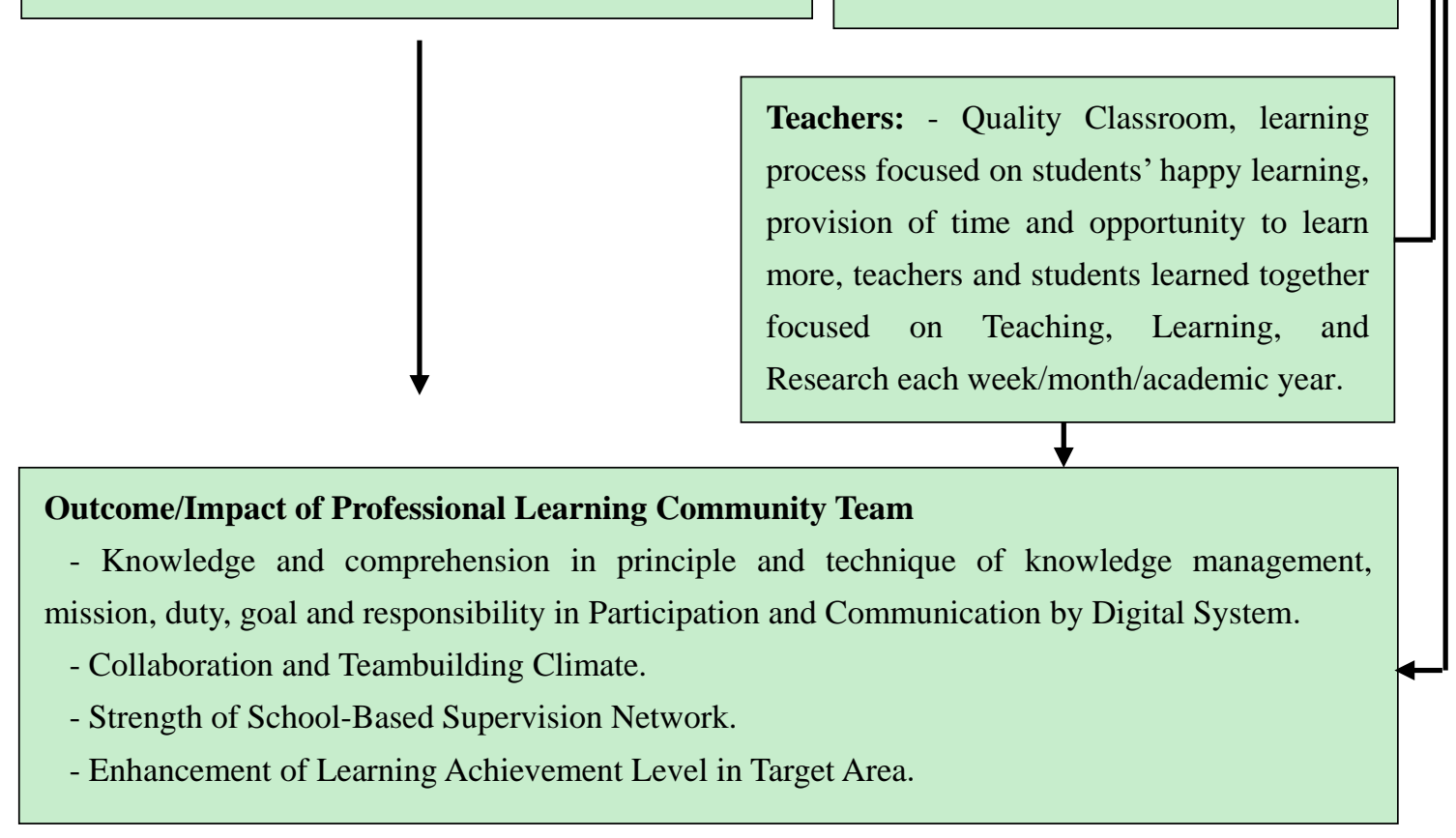

Figure 1. Conceptual Framework of School-Based Supervision

\section{Research Methodology}

\subsection{Construction and Development of Research Instruments}

The learning module of "School-Based Supervision of Students" had used research and development research methods consisted of the following 5 learning module development steps as follows:

1) Content analysis

1.1) The collaborative determination of issues in the development and planning of the module was conducted at the Faculty of Education, Educational Administration Masters' Program, Northeastern University, Khon Kaen Province. Thailand. The learning media should be based on an informal instructional process with minimum complexity. Systematically utilizing the developed learning module yielded.

1.2) Document analysis of the curriculum, related documents and research literatures in constructing the learning modules, especially those related to theoretical approaches in educational quality during the $21^{\text {st }}$ century, educational policies, appropriate strategies and innovative techniques in enhancing learning performance that concentrated on learners' self-practices and/or group- practices with teachers' supervising or coaching. 


\section{2) Design the module}

The construction and development of the learning module "School-Based Supervision for Students" was divided into 5 sub-modules: (1) Supervision Planning, (2) Technique for Higher-Order of Supervision, (3) Educational Quality Assurance, (4) Enhancement of Student Support System and (5) Development of Supervision Network. Each sub-module included activities in analytical thinking techniques and synthesis. On selection of an appropriate learning activity, one has to obtain basic knowledge in the learning management principle and determine the learning objective so that the students would go into their behavior according to the specified direction.

\section{3) Implement}

All of the 5 learning sub-modules were presented to 5 experts for evaluation for propriety and congruency of the content. It was revised, corrected and improved by the experts' recommendations. The team of experts indicated that the learning module's content should use a variety of diverse activities that could create innovative knowledge and ignite creativity. They also noted that the learning module could be applied to other educational programs and curriculums. Beside these, they also pointed out the weakness in the construction, that the efficiency of the trial test would be muted or non efficient if the participants lacked a handbook or reference guide of the learning module. The lack of a handbook was rectified, created, published and made available to all participants before the test trials began, thus making the learning module completed. Finally, the developed learning module, after experts' evaluation of its quality, in all 5 learning sub-modules in regards to propriety, feasibility, congruency, and utility, were evaluated by the experts.

\section{4) Developing and revision}

All 5 learning sub-modules were tested on non-target groups which were selected and also the group that volunteered to be groups of 1-5 students, sub-groups and tested individually on 9 students who were educational administrators and master's degree students in Educational Administration Program. The authors personally collected the data from the participants and were present during the tests. Trial tests with the sampling group were satisfactory and the authors carefully considered the learning module until they were confident that it was proficient and can meet or succeed the target criterion. Thought participation in the activities and observations were not perfect, they were continuously improved upon to find the strengths and weaknesses during the trial period. The learning modules were improved and revised as a part of the handbook for participants. The efficiency of the trial tests was 82.67/83.89. The 5 learning sub-modules then were published to be used in the final test with the target group of 12 master's degree students in educational administration, Northeastern University.

\section{5) Evaluation}

Knowledge, skill practice and the attitude of students should be factors when conducting evaluations. Behavioral observation, performance scrutiny, examination and evaluating findings should be performed and informed regularly to improve the efficiency of the activity. The construction steps and examination of the quality of learning achievements were as follows:

Evaluation tools to test included: 5.1) the learning achievement and 5.2) the students' satisfaction

5.1) Studied the theoretical approaches and rationales for constructing the learning achievement test, questionnaires with 4 multiple choice answers and 80 mandatory test items from 100, and applied Srisa-ard's (2002) criterion referenced test as the guidelines for creating the learning achievement test.

The learning achievement test was presented to the experts to evaluate the congruency between the test and its behavioral objectives. The scoring criteria were from +1 to -1 that the expert was given when he/she was confident in the test's measurement. The score +1 meant the measurement was based on the behavioral objective, the score 0 meant the expert was not confident of the test's measurement, and the score -1 meant the test did not provide the correct measurement based on the behavioral objective.

The index congruence between the test items and its behavioral objectives were analyzed using Item Objective Congruence (IOC) Formula (Pattiyatani, 1998). The IOC Index ranged from 0.5 to 1.00. After that, the tests with the IOC value were supervised by 14 school administrators, who acted as coaching teams to the participants, before offering them to a non-target group of 60 participants at J.P. Emerald Hotel, Yasothon province. The goal of the test was to study the participant's reaction and response to the trial test, the participants' reaction time in completing the test and comprehension of the presented questions. 
The obtained scores were analyzed to search for Item Difficulty $(\mathrm{P})$ and Item Discrimination in each test item. It was found that the Item Difficulty of the test ranged from 0.40 to 0.80 , and Item Discrimination ranged from 0.20 to 0.60. The Reliability of the Total Test (rtt) was determined by using the KR 20 formula and resulted in a rtt $=0.84$.

5.2) The learners' satisfaction test included the 12 item questionnaires to determine the students' satisfaction. It was studied from

5.2.1) The theoretical approach of satisfaction was studied from Soontrayut (2008).

5.2.2) The constructions and techniques in designing the satisfaction questionnaire were studied from Srisa-ard (2003).

5.2.3) The questionnaire was constructed based on its objective according to the 5 Level Rating Scale based on Likert's principle and used to determine the guidelines and rationale for constructing the satisfaction questionnaire.

The questionnaire was evaluated as follow:

The satisfaction questionnaire was presented to the group of experts for the evaluation of the congruence between question items and the behavioral objectives. The scoring criteria and the Index of Congruence between question items of the questionnaire and the behavioral objective used the same formula for the learning achievement test. We found that the IOC of the questionnaire ranged from 0.80 to 1.00. The group of experts recommended that the language of the questions should be written based on sentence structure and their obvious meaning. They also recommended that the question items with similar meanings be organized into one item.

The questionnaire was tested on the same non-target group of the learning achievement test. The Item Discrimination $\left(\mathrm{r}_{\mathrm{xy}}\right)$ ranged from 0.32 to 0.83 . The total issue reliability of the questionnaire was determined by using Cronbach's Alpha Coefficient (-Coefficient) which calculated the total issue reliability of the questionnaire was $=0.93$. The satisfaction questionnaire was then printed and used as a research tool to collect data.

\subsection{Data Collection}

2.2.1) The pre-test and posttest learning scores was collected from the learning achievement test to evaluate the students' theoretical knowledge.

2.2.2) The post-test and the test which was performed 2 weeks after that was collected to evaluate learning retention data.

2.2.3) The satisfaction questionnaire was used to collect the satisfaction data.

\subsection{Data Analysis}

2.3.1) The efficiency and effectiveness of the learning module "School-Based Supervision for Students" was analyzed as follows (Brahmawong, 1994):

We used $\mathrm{E}_{1} / \mathrm{E}_{2}$ Formula to search for the efficiency of the learning module as follows:

$$
\begin{aligned}
& E_{1}=\frac{\sum \mathrm{X} / \mathrm{N}}{A} X 100 \\
& E_{2}=\frac{\sum \mathrm{F} / \mathrm{N}}{B} \times 100
\end{aligned}
$$

2.3.2) The learning achievement of the learning module was compared its mean values of t-test (Dependent) comparative analysis between pre-test and post-test. (Srisa-ard, 2003)

2.3.3) The E.I. formula was used to analyze the effectiveness index of the learning module,

Effectiveness Index (E.I.) $=$ The sum of the post-test score - the sum of pre-test score

(Student Number X Full Score) - The sum of the pre-test score

2.3.4) The learning retention was analyzed and compared by using the t-test (Dependent) value and comparing it with the data after 2 weeks.

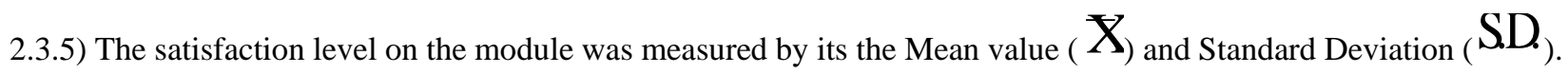




\section{Results}

1) The process efficiency and outcome of knowledge in the "School-Based Supervision for Students" module $\left(E_{1} / E_{2}\right)$ was $=84.76 / 82.16$, higher than the specified criterion of $80 / 80$.

2) The experts evaluated overall quality of the learning module in the highest level ( $\mathbf{X}_{=4.96, \text { S.D. }}=0.02$ ).

3) The effectiveness index for the learning module was $=0.7578$, indicating that the students obtained their knowledge $75.78 \%$.

4) The post-test learning achievement scores were significantly higher than the pre-test at 0.05 .

5) There were no significant differences between the students' learning achievement post-test scores and their post-test scores after 2 weeks, indicating that they achieved their learning retention through the module.

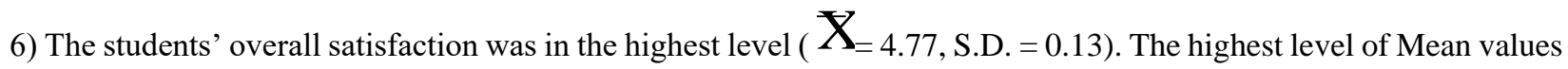
of each criterion consequently ranking were teachers' characteristics, contents, relationship between teachers and students, and theory of teaching skills as shown on Table 1.

Table 1. The students' satisfaction level for each criterion on "School-Based Supervision of Students (ED8013307) from high to low

\begin{tabular}{|c|c|c|c|}
\hline \multirow{2}{*}{ Criteria } & \multicolumn{2}{|c|}{ Satisfaction Level } & \multirow{2}{*}{ Interpretation } \\
\hline & $-\mathbf{x}$ & S.D. & \\
\hline 1. Teachers' characteristics & 4.66 & 0.50 & The most \\
\hline 2. Contents & 4.58 & 0.50 & The most \\
\hline 3. Relationship between teachers and students & 4.56 & 0.54 & The most \\
\hline 4. Theory of teaching skills & 4.52 & 0.53 & The most \\
\hline 5. Assessments and evaluations & 4.48 & 0.59 & More \\
\hline 6. Teaching skills of practical teachers & 4.45 & 0.57 & More \\
\hline 7. Learning supports & 4.34 & 0.60 & More \\
\hline Over all Satisfactions & 4.77 & 0.13 & The most \\
\hline
\end{tabular}

The results had shown the efficiency and effectiveness of using modules on internal supervision in the school. With suggestions, strengths, innovation, learning, and lessons on using the module, new knowledge could be applied in accordance with the local context. The result as post-practice recording scores (AAR: after action review) of learners has been increased. Thus, by using the internal supervision module lessons, it was an innovation on practical learning to enhance the

quality of education and quality class of students who had done self-learning before exchanging their knowledge with their peers and teachers in their classrooms as the process shown on Figure 2. 
Principles of module lessons the development of leader teachers in internal supervision in educational institutions. To reinforce critical thinking that is organized Learning that helps teacher leaders develop skills in learning management and improve school quality. The user of the module lesson in organizing Learning up

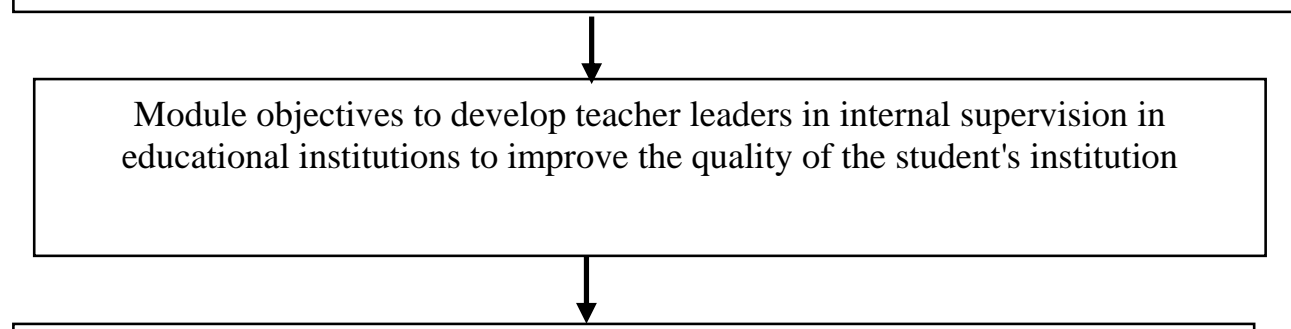

The goal of the module lesson

For teachers, leaders and administrators Teachers teaching in schools under the Office of the Education Commission

Basic or private, knowledgeable, and capable of self-learning, collaborative learning and research

Develop learning skills into practice

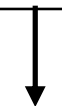

Content and development activities of the module lesson Phase 1 Preparation before entering development

Phase 2 Development consists of content:

Module 1 Defining Learning Objectives

Module 2 Consideration of learners' readiness

Module 3 Content Determination

Module 4 Organizing Learning Activities

Module 5 Evaluation

Module 6 Feedback

Phase 3 Integration with operations

Phase 4 Assessment after development

Procedures

1.Training

2.Learning by self-practice / group-practice

Module evaluation

1. Assessment of knowledge before joining the module lesson

2. Assessment of Learning Management, Module Participants

Figure 2. Using the internal supervision module lessons to enhance the quality of education and quality class of students 


\section{Discussions}

1) The efficiency index $\left(E_{1} / E_{2}\right)$ of the learning module "School-Based Supervision for Students", was $=84.76 / 82.16$ above the specified criterion 80/80. The student's post-test learning achievement scores were significantly higher than the pre-test at .05 , and there were no significant differences in post-test learning achievement scores and post-test learning achievement scores after 2 weeks, suggesting that learning retention was achieved through the learning module.

The success of the developing module was achieved from a well contributed and developing process. The authors had applied theoretical approach and practices from many successful studies to create and develop the module. The weakness was corrected and revised continuously that resulted in an efficient learning module. It was investigated by experts and found that the congruence of utility, possibility, and appropriateness in the highest level $(\bar{X}=4.59, \mathrm{SD}=$ 0.53 ) before offering the model to the classroom. The efficiency of the module shown the results accordance to the studies of Suda (2005); Donbundit (2008); Inruangsri (2011); Krongtanoen (2016); Hasakool, Chianchana, \& Stirayakorn (2016); Paphaphasid (2018); Chantarasombat (2020); Chantarasombat, \& Meekhamtong (2020); and Chantarasombat \& Sombatsakulkit (2021).

2) The student's overall satisfaction was at the highest level because the well-developed learning module was innovative, interesting, and had diverse learning activities that coincided with the student's competency. The learning activities in the well-prepared module challenged the interests of the students (Koonchon Na Ayutthaya, 1993; Charoenpong, 2012, July; Dechakup, 2011; Khammani, 2013; Chantarasombat, 2018). Students also viewed that the activities of the learning module were stimulating, the language of the questions were easy to understand which enabled them to answer them more accurately. The enjoyable learning atmosphere throughout the learning activities simplified the learning activities and provided a welcoming instructional ambiance.

The learning module motivated students because of their direct participation in the activities as they gained new knowledge from elements and surroundings that they were familiar with. Awareness and relatable environments produced good conduct through simple techniques without excess complicated activities. Familiarity stimulates learning interest as well as entices better cooperation, improved learning competency and the students could apply the knowledge in their daily life.

\section{Recommendations for Future Research}

1) The development of learning modules at the higher educational institutes level should be applied to support the development of creative thinking and $21^{\text {st }}$-century innovations.

2) Comparative study of the learning achievement between the learning module technique and other teaching techniques for educational management in higher education level.

\section{Acknowledgment}

The authors would like to express our appreciation to the Dean of the Faculty of Education, Northeastern University for providing and promoting the development and potentiality of the academics of the Doctoral Degree Program in Educational Administration and Leadership.

\section{References}

Brahmawong, C. (1994). The efficiency testing of instructional packages: Teaching handout of Educational technology and communication Unit 1-5. Sukothai Thammathirach Open University.

Chantarasombat, C. (2018). Coaching teams: How to improve educational Quality? Khon Kaen. Provincial Education Office; Pitchayabundit College.

Chantarasombat, C. (2020). The development of a learning module titled Educational Policy, Strategy and Strategic Plan (EDA6201) for students in Master of Educational degree. Journal of Education. Mahasarakham University, 14(1), 19-31. https://doi.org/10.5430/wje.v10n3p19

Chantarasombat, C., \& Meekhamtong, P. (2020). The development of Leader Teachers Development Program in learning Thai management for enhancing critical thinking of students in secondary research and development for the implementation of development program to develop teachers to be schools in Educational Administration Seminar Course for Master degree students majoring in Education Administration. Educational Research, 11(1), 10-20. https://doi.org/10.5430/wje.v10n3p19 
Chantarasombat, C., \& Sombatsakulkit, E. (2021). Doctoral Program Learning Module on Developing Leading Secondary School Teachers in Creative Thinking for Enhancement of Students' Learning Activities in Thailand. International Journal of Higher Education, 10(3), 138-149. https://doi.org/10.5430/ijhe.v10n3p138

Charoenpong, A. (2012, July). Module lesson titled Engineering Mechanics for high level of professional qualification. In The 5th National Conference on Technical Education. Faculty of Industrial Education, King Mongkut's University of Technology, North Bangkok.

Daryono, R. W., \& Rochmadi, S. (2020). Development of learning module to improve competency achievement in the department of civil engineering education in Indonesia. Psychology, Evaluation, and Technology in Educational Research, 3(1), 34-43. https://doi.org/10.33292/petier.v3i1.54

Dechakup, P. (2011). Student-centered instruction: Instructional approach, method and technique. Institute of Academic Development (IAD).

Donbundit, P. (2008). Developing of Chemistry module for university level by cycle of innovation. [Doctoral dissertation, Srinakharinwirot University]. http://thesis.swu.ac.th/swudis/Sci_Ed/Piyarat_D.pdf

Edmonds, H. L. S. (1994). A programmed instructional module for cardiac patients taking nitroglycerin. [Abstract]. [Doctoral dissertation, University of Pittsburgh]. https://elibrary.ru/item.asp?id=5722858

Efendi, Y., Musnir, D. N., \& Situmorang, R. (2019, February). Development of learning models for Programming Algorithms and Structure of Data I for E-Learning Assistance. In International Conference Primary Education Research Pivotal Literature and Research UNNES 2018 (IC PEOPLE UNNES 2018). Atlantis Press. https://doi.org/10.2991/icpeopleunnes-18.2019.57

Elmunsyah, H., Anggraeni, D. R., \& Handayani, A. N. (2017, November). Developing of fuzzy learning module for undergraduate Students. In 2017 International Conference on Education and Technology (2017 ICEduTech). Atlantis Press. https://doi.org/10.2991/icedutech-17.2018.42

Fajaryati, N., Nurkhamid, N., Pranoto, P. W., \& Muslikhin, M. (2016). E-Module development for the subject of Measuring Instruments and Measurement in Electronics Engineering Education. Journal Pendidikan Teknologi dan Kejuruan, 23(2), 191-199. https://doi.org/10.21831/jptk.v23i2.12302

Hasakool, R., Chianchana, C., \& Stirayakorn, P. (2016). The development of administration on short training course modules for education institutes under the Office of Vocational Education Commission. Technical Education Journal King Mongkut's University of Technology North Bangkok, 7(2), 52-60.

Inruangsri, S. (2011). Developing of Thai lives and culture module for the vocational students at Automotive Industry Technician College. [Master's thesis, Phranakhon Si Ayutthaya Rajabhat University].

Institute of Community Colleges. Ministry of Education, Thailand. (2018). 20-Year strategy for the Institute of Community Colleges (2018- 2037). Institute.

Khammani, T. (2013). Science of teaching: Body of knowledge for effective learning procedure (5th ed). Chulalongkorn University Printing.

Koonchon Na Ayudthaya, C. (1993). Program development document. Srinakharinwirot Pratoomwan University.

Kowitlawakul, Y., Chan, M. F., Tan, S. S. L., Soong, A. S. K., \& Chan, S. W. C. (2017). Development of an e-learning research module using multimedia instruction approach. CIN: Computers, Informatics, Nursing, 35(3), 158-168. https://doi.org/10.1097/CIN.0000000000000306

Krongtanoen, P. (2016). Development of Mathematics learning modules on sequence. [Master's thesis, Chiangmai University]. https://tdc.thailis.or.th/tdc/

Lawrence, G. (1973). Florida modules on generic teacher competencies: Module on modules. The University of Florida.

Panich, V. (2013). Teacher for students to build classrooms. Siam Commercial Foundation. Pattiyatani, S. (1998). Educational measurement (6th ed.). Prasan Printing.

Paphaphasid, A. (2018). Education innovation for doing research in class by creating learning material by yourselves and giving advice in class. King Mongkut's University of Technology North Bangkok.

Sigkabundit, S., \& Sigkabundit, S. (2011). Module. Srinakharinwirot University.

Srisa-ard, B. (2002). Teaching development (5th ed.). Ragdek Club. 
Srisa-ard, B. (2003). Foundation of research (8th ed). Suwiriyasan.

Suda, S. (2005). Developing of industrial control system for applying censor equipment for Diploma in Electrical Technology at Saraburi Technical College. [Master's thesis, King Mongkut's University of Technology Thonburi. https://tdc.thailis.or.th/tdc/

Suntrayuth, T. (2008). Reformed management: Research theory and practice in Education. Neatikul Printing.

\section{Copyrights}

Copyright for this article is retained by the author(s), with first publication rights granted to the journal.

This is an open-access article distributed under the terms and conditions of the Creative Commons Attribution license (http://creativecommons.org/licenses/by/4.0/). 